\title{
Mirar al Otro: explorando narrati- vas fronterizas entre Chile y Perú
}

\section{Gazing at the Other: exploring border Narratives between Chile and Peru}

\author{
Sebastián Reyes Gil \\ Facultad de Humanidades, Universidad de Santiago de Chile. Santiago, Chile. \\ sebastian.reyes.g@usach.cl
}

\section{Resumen}

El artículo presenta un análisis de tres textos literarios y una serie fotográfica sobre la frontera entre Chile y Perú. En los textos seleccionados se explora la mirada chilena sobre el otro peruano, para observar cómo estas obras descomponen los discursos sobre la identidad. Los materiales seleccionados son: la crónica "Chalaco Amor (sinopsis de novela)" (2004) de Pedro Lemebel; el cuento "El Ojo de Watanabe" (2013) de Andrea Jeftanovic; la novela Camanchaca (2009) de Diego Zúñiga; y la serie fotográfica Tacna (2014) de Paz Errázuriz.

Palabras clave: frontera, Chile, Perú, literatura, fotografía, Pedro Lemebel, Andrea Jeftanovic, Diego Zúñiga, Paz Errázuriz.

\begin{abstract}
This article presents an analysis of three literary texts and one photographic series about the border between Chile and Peru. Through the selected texts, the essay explores the Chilean gaze over the Peruvian otherness, to see how these works break official discourses on national identities. The selected works are: the chronicle "Chalaco amor (sinopsis de novela)" (2004), by Pedro Lemebel (2004); the short story "El Ojo de Watanabe" (2013) by Andrea Jeftanovic; the short novel Camanchaca (2009) by Diego Zuñiga; and the photography series Tacna (2014) by Paz Errázuriz.
\end{abstract}

Keywords: border, Chile, Peru, literature, photography, Pedro Lemebel, Andrea Jeftanovic, Diego Zúñiga, Paz Errázuriz. 


\section{De Tijuana a Tacna}

En el relato El etnógrafo de Jorge Luis Borges, Fred Murdock es enviado por su tutor de tesis a un territorio indígena y fronterizo, para vivir con los hombres rojos e investigarlos. Fred acepta porque: "Uno de sus mayores había muerto en las guerras de la frontera; esa antigua discordia de sus estirpes era un vínculo ahora” (párr. 1). Pero al regresar, Fred decide no escribir su investigación, después de aprender entre los hombres rojos un secreto que, le explica a su profesor, podría enunciar "de cien modos distintos y aún contradictorios" (párr. 2). Murdock además agrega: "No sé muy bien cómo decirle que el secreto es precioso y que ahora la ciencia, nuestra ciencia, me parece una mera frivolidad" (párr. 2). Lo que me interesa de la respuesta de Murdock a su profesor luego de haber vivido con los indígenas es cómo en el espacio fronterizo se produce un conocimiento que en última instancia es intraducible. En este artículo, exploro esa dimensión del lenguaje, que denomino aquí como escritura fronteriza. Concibo la frontera como una dimensión contradictoria, donde se demarcan y afirman intensamente las señas de identidad, pero también donde, paradojalmente, las categorías que nos definen se tornan ambiguas y difusas.

Cuando Balibar se pregunta qué es un borde, responde que la dificultad para definirlo radica en que no podemos atribuirle una esencia válida para todos los lugares, todos los tiempos, escalas físicas o individuos (75). El borde sería, por esencia, variable, ambiguo, polisémico y heterogéneo. Con la globalización, los nuevos flujos migratorios y de información, los estudios sobre bordes han proliferado en una creciente cantidad de artículos, libros, imágenes, reportajes, informes y estudios varios. Pero al mismo tiempo, los border studies corren el riesgo de perderse en medio de su falta de espesor y especificidad, en teorizaciones y aproximaciones multidisciplinarias que terminan minimizando su potencial crítico. Si casi todo puede ser analizado bajo el prisma de estos estudios (género, epistemología, artes, ciencias, etc.), ¿no estarían perdiendo los estudios de frontera su eficacia política y crítica?

Para evitar abstracciones fuera de la historia y politizar el borde en la crítica cultural, propongo aquí localizar esta exploración volviendo a una zona de conflicto, aquella entre las ciudades de Arica y Tacna, considerada aquí tanto geopolítica como simbólicamente. La pregunta que formulo es cómo las estéticas que se producen desde este borde o sobre él han interrogado las configuraciones de identidad. Escribiendo sobre Tijuana, Ian Chambers se refiere a los bordes como espacios violentamente impuestos, pero también culturalmente productivos. El espacio fronterizo funciona como "framing device", es decir como dispositivo y estrategia de enmarcación o delimitación, dando forma y contenido a lo que se define como propio, al mismo tiempo que señalando aquello que se excluye. El borde se establece para dejar algo fuera, y sin embargo,

revela en la intensidad misma de su biopolítica, los protocolos ocultos que definen y confinan a su población. Los bordes nos fuerzan a reconsiderar las configuraciones históricas, políticas y culturales, que sostienen su necesidad. 
Ellos traen de regreso al encuadre lo que habían previamente diseñado para excluir: Al derrotado, al subalterno, al otro; otras historias, otros territorios de pertenencia y devenir, presionados contra este aparente marco infranqueable (Chambers ix, traducción propia $)^{1}$.

El borde es una franja paradojal en la cual los derechos de ciudadanía y sus reglas son confirmados, usurpados o burlados. Lo que se puede portar en el paso fronterizo, simbólica o materialmente, es estrictamente custodiado; así, el cuerpo y los objetos que pasan pueden ser, por ejemplo, admitidos, confiscados o traficados ilegalmente. Al pasar de un país a otro, se nos exige reafirmar y probar quiénes somos, de dónde provenimos, a qué sexo pertenecemos, etc. La rigurosa necesidad de los aparatos de vigilancia (policía, aduana) por demostrar ciertas señas de identidad se debe precisamente a que en el paso fronterizo estas manifiestan su fragilidad, artificialidad y arbitrariedad.

Las reflexiones de Chambers se encuentran en el contexto de los análisis sobre Tijuana, ciudad que ha sido en general, junto con la frontera México/EeuU, un gran laboratorio para los estudios culturales latinoamericanos. Como veremos, la comparación entre San Diego/Tijuana y Arica/Tacna es pertinente: Chile representaría para los inmigrantes peruanos la utopía neoliberal y capitalista (EEUU), como tierra de oportunidades para trabajar y ahorrar. Tacna sería comparable a Tijuana, la ciudad del placer, el ocio y el consumo turístico. Pero también la comparación con la frontera de México y EEuU es pertinente aquí según la concepción que articuló Gloria Anzaldúa de borderland. Fue esta la zona desde la que se produjo Borderlands/La Frontera: The New Mestiza (1987), texto crucial para pensar lo que denomino escritura fronteriza. Aquí Anzaldúa manifiesta como propósito: "the breaking down of paradigms [...] the straddling of two or more cultures" (80), es decir, un habitar simultáneo en dos o más culturas, que sostenga las diferencias y las tensiones. Cito entonces a esta chicana particularmente por su visión dialéctica del borde como una zona de apertura y disputa en vez de reconciliación y síntesis.

La identidad chilena es una compleja construcción cultural que se encontraría expuesta y amenazada en su límite. Aunque sea imposible caracterizar la identidad chilena aquí ${ }^{2}$, se puede indicar una primera distinción: nuestra identidad sufriría de un "déficit de espesor", debido a "la pobreza de aportes culturales de origen étnico o

1 En el original se lee: "reveals, in the very intensity of its biopolitics, the underlying protocols that define and confine its own domestic population. Borders force us to reconsider the historical, political, and cultural configurations that gave rise to their necessity. They bring back into the picture what they were previously designed to exclude: the defeated, the subaltern, the other; other histories, other territories of belonging and becoming, push up against this seemingly impassable framing".

2 Larraín, por ejemplo, después de leer 57 libros relativos a la identidad como carácter, concluye que el chileno es considerado como: "inclinado al orden y a lo establecido, sociable y dependiente afectivamente de los demás, cálido, cordial, con sentido del humor, hospitalario, generoso, comprensivo, dependiente de la opinión ajena, inseguro, susceptible, sobrio y moderado, inhibido" (161). 
demográfico" (Subercaseaux 159). En cambio, en países como México o Perú, “tanto las culturas precolombinas como la colonización española dejaron una fuerte impronta de identidades que impregnaron culturalmente a las nuevas repúblicas" (155). La nación chilena habría sido sostenida, más que en otras latitudes, según creaciones "desde arriba", es decir, de acuerdo a pactos civiles de élites ilustradas, sobre todo a partir de la Independencia. Luego, con la Guerra del Pacífico, se habrían creado ciertos mitos y ritos populares, pero en general de una multiculturalidad "mutilada" (161). Entonces, la identidad chilena sería una particularmente frágil y, por lo mismo, necesitada de constantes reafirmaciones. Su construcción requiere, según Subercaseaux, fundarse en un auténtico desarrollo y profundización de la democracia que incluya las diferencias de los ciudadanos que la componen. En vez de eso, en el contexto de la globalización, Chile se ve a sí mismo y se proyecta hacia los demás como una nación de consumidores y emprendedores (159). Por otra parte, para el sociólogo Jorge Larraín:

Desde Portales en adelante se les ha considerado (a Perú y Bolivia) como los enemigos naturales de Chile. Frente a ellos el chileno medio tiene un sentimiento de orgullo y superioridad [...] El hecho de ser países con grandes mayorías indígenas, con una fuerte cultura autóctona no plenamente europea, reafirma el sentido racista y antiindígena, muchas veces bien camuflado, que existe en Chile (265, énfasis nuestro).

Los chilenos se identifican como superiores a los vecinos del norte según la misma negación de los indígenas que efectuaron en el interior de su propio país ${ }^{3}$. Perú es visto como inferior debido a su raigambre indígena, es decir, que vemos negativamente en el otro lo que negamos en nosotros. En una encuesta de 2014 realizada en Santiago, frente al planteamiento "Chile es un país más desarrollado que sus países vecinos pues hay menos indígenas", el 41,5\% señala que está "totalmente de acuerdo" ("Racismo" 2014). Hay, por otra parte, aspectos "positivos" que los chilenos observan en los peruanos. Se considera a Perú un país de cultura culinaria superior, y algunos opinan que los peruanos son personas educadas. Esto último lo afirmaron empleadoras de mujeres en casas particulares, pues las "nanas" peruanas ayudarían a los niños en las tareas y a pronunciar mejor el castellano (Stefoni 108). Pero, salvo excepciones como estas, las imágenes sobre los peruanos son negativas y vinculadas a opiniones discriminadoras:

Y la gente es de muy bajos recursos, vienen como arrancando de allá de la pobreza, tienen un nivel cultural muy bajo en cuanto a hábitos, en cuanto a actitudes, a todo. Traen enfermedades, hay mucha tuberculosis, traen infecciones que aquí los chilenos no tienen, infecciones vaginales, sífilis, infecciones de

3 Otra versión de esta negación del pasado se encuentra en El laberinto de la soledad (1950) de Octavio Paz, y en su versión chilena, en Madres y huachos: alegorías del mestizaje chileno (1991) de Sonia Montecino. La negación de los indígenas en la identidad ha sido, en cualquier caso, extensamente debatida por los estudios de colonialidad y poscolonialidad en América Latina. 
transmisión sexual. (Silvia, mujer chilena que trabaja en un centro de atención de salud) (cit. en Stefoni 104).

En una opinión xenófoba como esta, se advierten los lugares comunes que se asocian al extranjero: son "bárbaros" y van a contaminar el cuerpo y la moral del país que los recibe. La idea de la enfermedad asociada a los extranjeros se da en muchas culturas, y fue durante la Conquista una metáfora generalizada para referirse a los indígenas, que eran sin embargo los nativos. Los españoles hablaban de "infección moral", expresada en conductas que ellos consideraban dudosas, como aquellas que desde su visión de mundo consideraban como adulterio y sodomía. Mientras tanto, se expandían por doquier los virus transmitidos por los europeos a las poblaciones nativas.

Para los peruanos, los chilenos serían no solo los vencedores y usurpadores de territorio en la Guerra del Pacífico (1879-1883), sino que además, dado el "éxito" económico del modelo neoliberal instaurado por la dictadura de Pinochet, se habrían transformado en seres arrogantes con sentimientos de superioridad. El escritor peruano Jaime Baily, en su novela Morirás mañana 2. El misterio de Alma Rossi (2011), describe los pensamientos de su protagonista, el peruano Javier Garcés, hacia los chilenos:

Les gusta demasiado el dinero. Venden a su madre por dinero [...] Son trepadores, arribistas, y lo peor es que han trepado y ya se sienten más arriba que los demás y te miran para abajo. Y si bien han sabido hacer dinero y sobre todo ahorrarlo, esconden dos defectos que me resultan particularmente despreciables: son avaros, tacaños, miserables, son roñosos, son trémulos y cobardes para gastar, guardan la plata por falta de audacia, por pusilánimes, porque piensan en su jubilación, no en darse la gran vida, como los argentinos, que no ahorran un carajo pero se divierten mucho más. Y luego me irrita que los chilenos miren ahora para abajo a sus vecinos sólo por esa sensación de bonanza que los embarga cuando antes debieran mirarse al espejo (cit. en "Jaime Baily y los Chilenos" 2011).

Los chilenos, según esta visión, son mezquinos y utilitaristas, personas motivadas fundamentalmente por intereses económicos. Una encuesta de 2012 desarrollada por la Fundación Imagen Chile indica que un 52\% de peruanos entrevistados declara percibir a los chilenos como "agresivos", un $42 \%$ "fríos" y un $24 \%$ de "mentalidad exitosa".

A partir de este breve contexto, podemos preguntarnos: ¿ cómo las obras literarias y las fotografías aquí seleccionadas desestabilizan la mirada chilena sobre lo peruano y lo chileno? Mi argumento es que, con mayor o menor intensidad, los textos realizan una serie de subversiones sobre la identidad nacional, mediante escrituras fronterizas que desmontan el tiempo y el espacio, las posiciones de la mirada, las marcas de clase, etnia y género. Y lo hacen innovando en las formas literarias. Mirar al otro en estos textos es mirar a Tacna como una ciudad de frontera que se configura como idea y fachada para la mirada chilena. Al mismo tiempo, estas narrativas subvierten las nociones del otro peruano y del yo chileno, denotando jerarquías simbólicas donde ocurren el 
abuso y la explotación. Propongo que estos textos literarios, así como la fotografía de Paz Errázuriz, son fronterizos por sus capacidades de dislocar las fijaciones culturales de la frontera y la identidad nacional, la petrificación de los estereotipos, las posiciones jerárquicas en relación al otro y los mecanismos de segregación. Especialmente, los textos de Lemebel y Jeftanovic contrarían las convenciones formales y temáticas, donde los límites de la identidad resultan siempre inconclusos, abiertos y frágiles.

\section{Lemebel: una loca frontera}

En las crónicas de Adiós mariquita linda (2004) de Pedro Lemebel, el cronista va mutando de acuerdo a los viajes y sus encuentros, de manera que: "Los cuerpos en acción dentro de este libro son todos ellos cuerpos desertores, que se han fugado de las cartografías del orden, de la moral y de la riqueza" (Richard 156). En esta colección de crónicas, el relato de Lemebel "Chalaco Amor (sinopsis de novela)" pone en escena diferentes cruces y desbordes de identidad en su viaje por Perú.

La narración comienza con Pedro, quien al intentar cruzar distraído una calle santiaguina, es rescatado por un muchacho peruano antes de ser atropellado. Pedro dice deberle la vida al joven, el que a su vez miente, afirmando que es ecuatoriano, ya que "algunos peruanos no se reconocen, por la chilena segregación" (Lemebel 111). En un bar donde Pedro invita al muchacho a tomar cerveza, el cronista narra sus pasadas andanzas por Perú, retrotrayéndonos a la Tacna de 1980, ciudad por la que Pedro debía pasar y cambiar dólares, para continuar rumbo a Machu-Picchu. En la plaza de Tacna conoce al joven peruano Roger, que viene regresando a Perú desde Iquique, el puerto chileno con zona franca donde el chico ha comprado "bluyines" para venderlos en Perú. Roger debe tomar un desvío por el puerto peruano de Ilo para evadir los controles aduaneros que pueden requisarle su mercancía ilegal. Lemebel cae prendado ante los ojos de Roger y junto a él pasea por Tacna, ese "pueblo de frontera" donde van "recorriendo juntos cantinas oscuras y mercados cevicheros, riéndonos a pata suelta con los parroquianos, relatándonos su anecdotario gitano de burreros y movidas de contrabando" (113). Lemebel le dice al chico que le gusta Perú, porque ahí "no es un pecado tener los ojos pequeños", para agregar que: "Tengo un algo de por aquí" (114).

Así, Pedro comienza una identificación con lo peruano, mientras va dejando atrás lo chileno, como por ejemplo su rol de turista (el puerto de Ilo queda fuera de la ruta turística). Como dos personajes de la picaresca, los compañeros de viaje se adentran en el desierto en un bus que es detenido por los militares. Una voz ordena "que baje el chileno" (115), entonces Lemebel es detenido por varias horas e interrogado por la PIP (Policía de Investigaciones del Perú). Lo han interceptado porque ese mismo día Perú ha declarado la guerra a Ecuador, y el andar del cronista fuera de la ruta turística es sospechoso, según le dicen los policías. Pedro piensa que "en ese lugar 
yo podía ser Mata Hari" (116), hasta que finalmente es enviado por los policías a un hotel de Ilo, donde se vuelve a encontrar secretamente con Roger, que entra al hotel sin autorización para invitar a Pedro un "pito". En ese momento, Lemebel escribe:

\footnotetext{
Y ya no pensaba en mi condición de prisionero de guerra, ni siquiera los acorazados de la bahía me daban miedo cuando el Roger encendió el fumo, lo puso delicadamente en mis labios y suspirando se tendió largo en la otra cama. Parecemos dos barcos a la deriva, recité conteniendo el humo verde. ¿Dos barcos de guerra?, preguntó aspirando el cuete compartido. Como los de la guerra del Pacífico, dije divertida. Entonces yo sería el acorazado Huáscar espoleando a la corbeta chilena Esmeralda. No, Roger, esta noche bélica prefiero creer que somos dos navíos en remanso (119).
}

Finalmente, cuando Roger y Pedro están a punto de compartir una de las dos camas del hotel, entra la policía y los expulsan. Pedro es llevado al terminal de bus para que se vaya de Ilo y Roger es "cogido de los brazos como un forajido". Esta crónica de las andanzas de Lemebel invierte y trafica posiciones de identidad, especialmente las marcas interrelacionadas de sexualidad, etnia y nacionalidad. Primero, Lemebel nos invita a detenernos en el inmigrante peruano en las calles de Santiago del 2004, transformándolo en un héroe que lo salva de ser atropellado, y ese romanticismo casual de esquina, zona fronteriza en la ciudad de cruces, devenires y homosexuales, lo retrotrae a su encuentro con otro muchacho peruano, Roger, para luego, en los avatares del deseo, disputar simbólicamente los límites geopolíticos, de género y nacionales, en la metáfora de los barcos de guerra, de ser Mata Hari, de mimetizarse con lo peruano ya que sus ojos pequeños (rasgo indígena) ya "no son pecado". En "Chalaco Amor" se intenta romper los prejuicios xenofóbicos subvirtiendo el estatus inferior impuesto al peruano por la mirada chilena.

El primer muchacho peruano oculta su identidad en un Santiago donde es discriminado, y Lemebel le devuelve la mano poniéndose en el lugar de él, a través del relato, al ser detenido en otro tiempo, en Perú, por ser chileno. Finalmente, la alianza soñada entre los cuerpos funciona como restitución pasajera pero siempre fallida (nunca concretan físicamente el deseo) de unión entre los dos países. La crónica moviliza las zonas fronterizas (esquina, plaza, bar, puerto, aduana, etc.) donde Lemebel burla las imágenes que lo fijan como chileno en su juego imaginario de mímesis y diferencias con el otro peruano. Sólo cuando es detenido por la PIP exige sus derechos como turista chileno, restituyendo por conveniencia pasajera y casual su chilenidad de papel.

En el libro de crónicas Adiós mariquita linda fueron además publicados una serie de dibujos y notas escritas a mano por Lemebel en sus viajes por Perú. Richard ha comentado que, frente a la sobreexposición de la privacidad de Lemebel en la publicación de sus crónicas en los medios, "los dibujos del autor exhiben aquí el discreto pliegue interior de un secreto todavía inconfesado" (157). Además de este gesto de discreción e intimidad, encontramos en estas crónicas la publicación de una página 
de su diario de viaje al Perú ese año 80, donde aparecen palabras sueltas, relacionadas entre sí, pero dispuestas caóticamente en la página: PEDRO, POLICIA, PITOS, PERUANO, PIP, TRONCHO, TACNA, TRAGOS, por ejemplo, de modo que van formando un caligrama que rompe con la linealidad de la escritura, asociando palabras según inusitados juegos que mezclan el formato de las memorias y los diarios de viaje, la ficción y la crónica, la pureza y homogeneidad de los géneros narrativos, con la hibridez y el pastiche de dibujos, fotos y palabras sueltas, huachas. La frontera Arica-Tacna le proporciona al escritor viajero entonces una posibilidad de cruzarse y mezclarse con el otro peruano, que aparece en el texto como fetiche del joven plebeyo, del pícaro que lo lleva a perderse al mismo tiempo en una estética de desvíos y derivas. En "Chalaco amor", pasar por la frontera implica hacerse pasar por otro (Mata Hari, peruano, turista, "amigo de improviso", hippie, etc.), descorriendo los límites de la identidad, desafiando las divisiones impuestas por los aparatos de la ideología nacionalista y armando una "loca" geografía donde los signos territoriales de la nación y las marcas fálicas del control, la vigilancia y la guerra se desordenan en uniones fugaces de un deseo homosexual a la deriva.

\section{"El ojo Watanabe" y la disputa de miradas}

Otra escena contemporánea sobre la frontera Arica-Tacna se encuentra en el cuento "El ojo de Watanabe" de Andrea Jeftanonic, aparecido en la antología de varios autores publicada por la misma escritora, .cl Textos de frontera (2012). En el relato, una escritora chilena navega junto al poeta peruano José Watanabe (1947-2007) por las aguas fronterizas de la disputa marítima entre Chile y Perú. Se trata de un viaje en formato de crónica ficcional que tiene como propósito decidir los límites marítimos entre ambos países. Durante la navegación, la narradora realiza una entrevista a Watanabe, quien habla sobre las relaciones entre Chile y Perú, entre japoneses y peruanos, entre oriente y occidente. Mediante una serie de montajes y desmontajes narrativos, la escritura de Jeftanovic desdibuja la cartografía geopolítica de la zona marítima en disputa y sus jerarquías simbólicas.

El cuento comienza con las dos siguientes frases: "El ojo rasgado de Watanabe se posa en mi ojo redondo. Su ojo oriental se despliega sobre mi ojo occidental" (359). De esta manera, la narración se abre con un cuestionamiento de la perspectiva occidental sobre oriente. Cuando le pregunta a Watanabe: “¿Cómo viaja el ojo de Oriente a Occidente?" (360), la narración interviene la manera en que occidente inventa o coloniza al oriente. Propone así voltear la perspectiva y las coordenadas del viaje para descolonizar el orientalismo (Said) cultural, al buscar el reconocimiento o memoria de viajes inversos, por ejemplo, desde oriente (Japón) a occidente (Perú). Al preguntar cómo viaja "el ojo", lo que se interroga es la posición de la mirada y el lugar de poder de quien observa y narra. Con esta apertura, el cuento pone en entredicho los dis- 
cursos oficiales de la nación y sus cartografías culturales, y produce en la narración un extrañamiento entendido como extranjería (ser oriental y japonés en occidente y Perú), pero también como estrategia poética.

Luego, cuando José Watanabe relata su temporada estando enfermo en Alemania, cuenta que: "Un amigo poeta decía: 'El poeta no puede hablar, está aprendiendo las sílabas"” (364). De modo parecido, Deleuze proponía, contra un lenguaje que "propaga órdenes", otro que "sería algo así como la línea de fuga del lenguaje, hablar con su propia lengua como extranjero, hacer un uso minoritario del lenguaje" (Diálogos 28). Ser poeta, como ser extraño, otorga al "Ojo de Watanabe" la posibilidad de navegar y escribir desde la inestabilidad y la nomadía. La salida al mar en el cuento es una partida desde el orden hacia una comprobación imposible por encontrar una división; la búsqueda infructuosa de los límites definitivos geopolíticos, lingüísticos, escriturales y de identidad. En esta búsqueda surge el pasado según trazos inconclusos de memoria. Watanabe recuerda, por ejemplo, brevemente una historia de la violencia durante la Segunda Guerra Mundial encarnadas en su familia: "Mi padre nunca dijo 'los gringos mataron treinta y seis mil personas en Hiroshima, eso no podemos perdonarlo'. No, no lo dijo nunca. Se escondió entre los cañaverales y guardó silencio. Al final de la Segunda Guerra Mundial, el gobierno de Prado no aceptó el regreso de los nipones deportados y muchos fueron enviados de regreso a Japón" (Jeftanovic 362). En el viaje por las aguas marítimas de una borrosa frontera entre Chile y Perú, Watanabe reconstituye los fragmentos de una biografía violentada por ser japonés, identidad cultural en este caso silenciada por el padre melancólico y posiblemente temeroso de represalias xenofóbicas. Luego, entre el poeta y la narradora se manifiestan apenas en retazos las conflictivas relaciones entre Chile y Perú, como si el padre volviera a la escena, haciendo que varios pasados se crucen.

La escritura fronteriza en Jeftanovic se manifiesta mediante la descomposición del tiempo y el espacio. A través del diálogo, del intercambio de palabras y experiencias, se van reconociendo los objetos robados por los respectivos países, como por ejemplo, los libros peruanos robados de la guerra que hay en la Biblioteca Nacional de Chile. Según la narración, los peruanos, a su vez, tienen en su museo dos pistolas históricas; la pistola del general Manuel Baquedano (general chileno de la Guerra del Pacífico) y la de Salvador Allende. La historia de los objetos y su captura museística, entendido el museo como resguardo de la memoria nacional, significa volver sobre los conflictos y traumas silenciados: Guerra del Pacífico, golpe militar en Chile del año 1973. En esta narración, la búsqueda por los límites -causa de la navegación en aguas que pueden ser de nadie- permite que en estas transferencias de imágenes, recuerdos, palabras y objetos, sean posibles los relatos privados de lo íntimo, la enfermedad, el dolor del poeta, su larga depresión, la muerte de sus hermanos. Lo privado (la biografía) se transpone con lo público (la historia oficial de las guerras, de las naciones), desestabilizando las distinciones entre ambas esferas. Mientras dura el viaje, las relaciones entre naciones, cuerpos e identidades se recomponen en forma diferente a la oficial. 
Como contrapunto en este mar de nadie, se señalan las marcas de ubicación: "sé que estamos en la latitud 12, longitud 77 oeste" (362), pero solo para puntear irónicamente la arbitrariedad de la cartografía política nacional.

$\mathrm{Al}$ igual que en la crónica de Lemebel, los viajeros aquí también se separan. Al terminar el cuento, la narradora y el poeta suben cada uno a su embarcación y: "En el preciso momento que íbamos a proceder a la operación salomónica, una corriente marina lleva cada bote a una zona distante. El agua turbulenta nos arrastra en direcciones opuestas" (369). "El Ojo de Watanabe" es de esta manera la narración de una imposibilidad por establecer la frontera definitiva entre oriente y occidente, la realidad y la ficción, la crónica y la literatura, lo nacional y lo extranjero, lo personal y lo político, la historia oficial y los "restos" de una memoria del dolor y la violencia.

\section{Camanchaca y el otro invisible}

En la novela chilena Camanchaca (2009) de Diego Zúñiga, el protagonista es un joven de veinte años que debe viajar con su padre a Tacna para someterse a un tratamiento dental. Esta vez el viaje es desde Chile hacia Perú en auto por el desierto, y al mismo tiempo uno hacia el pasado del protagonista. Mediante una escritura basada en insinuaciones, el narrador cuenta fragmentos de su infancia en la ciudad de Iquique, como el divorcio de sus padres, la relación con su madre, la muerte en extrañas circunstancias, en la carretera, de su tío Neno.

En Camanchaca, Tacna aparece desde las primeras páginas como ciudad conveniente para tratamientos dentales a menor costo: "debemos ir a Tacna porque si no podría perder mis dientes" (13). Por una enfermedad que el hijo parece estar heredando, la madre del protagonista ha perdido todos los dientes y debe usar una placa. El muchacho tiene el problema de la dentadura desde la infancia, una amenaza que ha estado siempre presente. El miedo a la pérdida, representado en los dientes, puede significar en la novela una carencia generalizada o difusa de la identidad. La escritura en primera persona está recorrida por el temor a la desaparición y la disolución, ya que los objetos y los hechos del pasado tienden a diluirse, al igual que los lazos familiares. La novela aparece como un tour de force por recordar y armar una biografía, obra que avanza a tientas en la camanchaca. Recomponer la dentadura significa curar las heridas de la biografía. Pero esta recomposición es imposible: en la narración, los sucesos traumáticos se pierden en la memoria, la neblina, el desierto y la noche.

La boca enferma del protagonista empeora; sangra de noche y por la mañana tiñe los dientes de rojo. Al lavárselos, como permanente constatación del dolor emocional, la "boca está llena de pasta de diente con sangre" (91). Finalmente, el protagonista logra llegar a Tacna y realizarse el tratamiento dental. Se menciona además que el muchacho ha viajado con una lista de compras que le ha encargado su madre. La descripción que se hace de la ciudad en la novela es escasa: "Caminamos hacia el hotel. No tengo 
idea de cómo se llama la calle, pero hay varios casinos. A nuestro lado caminan unos chilenos. Conversan en voz alta. Esto parece Chile, dice uno de ellos, como si fuera la reflexión más importante de su vida" (117).

Las pocas imágenes de la ciudad peruana de la frontera descritas por el narrador muestran el turismo chileno y la asimilación de Perú a Chile. Mientras conduce por esa ciudad, el padre del protagonista se refiere al mal gusto que tienen los peruanos y a la falta de semáforos y luces en las calles. El muchacho dice que su padre: "Ahora me habla de las carreteras peruanas, de cómo conducen los peruanos en las malas carreteras" (117), típica metáfora de lo extranjero como barbárico. Al final de la breve novela, dirigiéndose padre e hijo de regreso a Chile por la ruta desértica en el lado peruano, ocurre un atropello:

Nos dirigimos hacia la aduana. Vamos abandonando la ciudad. La radio no capta ninguna señal. No hay personas. En el desierto no hay personas. No hay dragones, tampoco. Todo está oscuro. Muy oscuro. Un golpe. Una trizadura. Mi papá no alcanza a frenar. El bulto en la mitad de la carretera. No hay nadie. No hay más personas. En el parabrisas hay una trizadura. Mi papá me mira, coloca su mano en mi muslo y me dice tranquilo. Pone reversa. Mueve el volante, lo esquiva y acelera. Se ven las luces de la aduana. No sé dónde quedó la lista (119).

El atropello aparentemente de un peruano en la mitad del desierto en el viaje de regreso, con los dientes del protagonista ahora salvados, muestran el atropello al peruano en general. La trizadura del parabrisas que interrumpe la mirada de los chilenos es la huella de la persona sin identidad, que han matado o herido gravemente en un camino de regreso "sin señales". Ese bulto que arrollan es un pasar sobre el otro, el sujeto anónimo que no alcanza a detener la trayectoria avasalladora de los turistas chilenos.

Algo más adelante, padre e hijo logran cruzar a Chile. Tacna ha quedado atrás y cumplido su función, los chilenos han comido, paseado brevemente y realizado el urgente tratamiento dental. El resultado, el saldo de este viaje, es un posible muerto atropellado en la carretera. Pero sorprendentemente al otro lado de la aduana, conduciendo ya por el desierto chileno, el joven protagonista junto a su padre dice ver: "Niños y viejos. En la mitad de la carretera. Los veo en mitad del desierto, y mi papá los esquiva, acelera y los esquiva" (120). Seres fantasmales como zombies, que aparecen en la mitad del camino, sin nombre, rostro, ciudadanía, identidad, deben ser esquivados por el automóvil chileno. Los cuerpos aparecen y desparecen en la noche semi-invisibles en una neblina que borra líneas divisorias, habitantes de la frontera que la historia de la violencia ha dejado entre estas dos ciudades y sus alrededores. $\mathrm{Si}$, por una parte, estos seres invisibles hacen recordar el accidente que, en la carretera y en extrañas circunstancias, sufrió el tío del narrador, podemos pensar también que son los sujetos subalternos sin voz que pasan al otro lado, como burreros o trabajadores, sujetos negados por la ley, que solo son considerados por ella al infringirla. Quienes en cambio sí pueden cometer un delito y no ser sancionados son los chilenos. Chile y 
sus luces en el paso de Chacalluta prometen al protagonista resguardo e impunidad, el olvido del crimen que ha cometido su padre, y sin embargo estos seres que aparecen en la camanchaca representan la imposibilidad de dejar atrás, de eliminar, a quienes no pueden ser nombrados o identificados, y que acechan el trayecto de regreso a casa.

\section{Tacna: fotografía, fachadas y poses}

La serie de fotografías Tacna de Paz Errázuriz, muestra cómo parte central de esa ciudad se ha transformado en la urbe de los tratamientos de belleza, la limpieza, el arreglo dental y la sonrisa perfecta a bajo costo para los turistas chilenos. El efecto estético de la oferta dentífrica, en particular, ha modificado la fachada de las principales calles de la ciudad con las imágenes de familias caucásicas y sus sonrisas de blanca felicidad. Pero junto con la promesa del arreglo estético, las fotografías publicitarias registradas por Errázuriz también muestran el horror y la monstruosidad de la boca en descomposición. La boca y sus aperturas, la encía sangrante o podrida, la dentadura y sus desperfectos, sus caries y malformaciones, asaltan el espacio visual de la ciudad que se ofrece a la mirada clientelar chilena con la obscenidad del interior bucal en sus más macabras imágenes de la herida, lo infectado, lo putrefacto, lo chueco, lo deforme. La ciudad invita así a ver lo grotesco, al mismo tiempo que promete al turista chileno una multiplicidad de arreglos dentales y estéticos, jugar en sus casinos, comer en sus restaurantes y, detrás de la fachada más evidente, tener sexo con sus mujeres.

Otros sin número de tratamientos ofrece la ciudad salón de belleza, como arreglar callos, limpiar hongos o arrancar verrugas, todas ofertas estéticas que vuelcan sobre la calle las mil imperfecciones del cuerpo. Ciudad odontológica, oftalmológica, dermatológica, ofrece también limpiar intestinos y quitar cualquier imperfecto en la apariencia e interior del chileno, que en sus calles tiene la posibilidad de reafirmar sobre todo su propia fachada. Híbrido entre feria callejera de peluquería, manicure y clínica, Tacna se erige al ojo del turista chileno como un espejo para reflejar su máscara de pretensiones.

Al mismo tiempo, y detrás de esta escenografía de pendón y cartel, hacia los cerros periféricos, Tacna ofrece los servicios sexuales de cientos de mujeres locales o que vienen de otras ciudades peruanas y extranjeras, que habitan una serie de prostíbulos. Algunos de ellos están ahora en ruinas, como "Casa de muñecas" (fig. 10), mientras que otros en plenos funcionamiento. Las discusiones políticas recientes exacerbadas por la prensa, respecto a límites entre Chile y Perú, la exposición constante en los medios de líneas fronterizas y mapas, junto con las ofertas estéticas de arreglo corporal, esconden los cuerpos explotados y acosados de la zona fronteriza, y en particular el cuerpo de la mujer. Temporeras, trabajadoras en casas particulares, mujeres narcotraficantes o "burreras" y trabajadoras sexuales son algunos casos de mujeres segregadas por las condiciones de pobreza. 
FIGURA 1

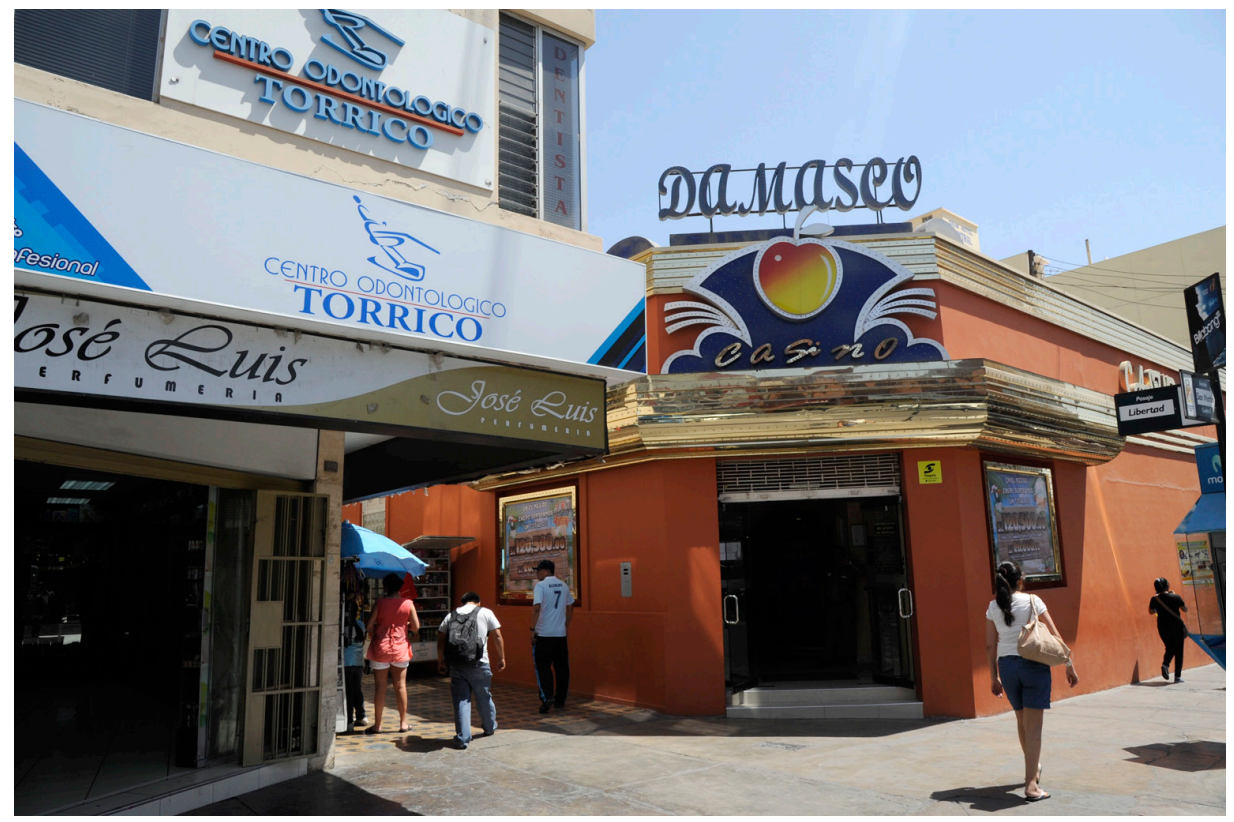

FIGURA 2

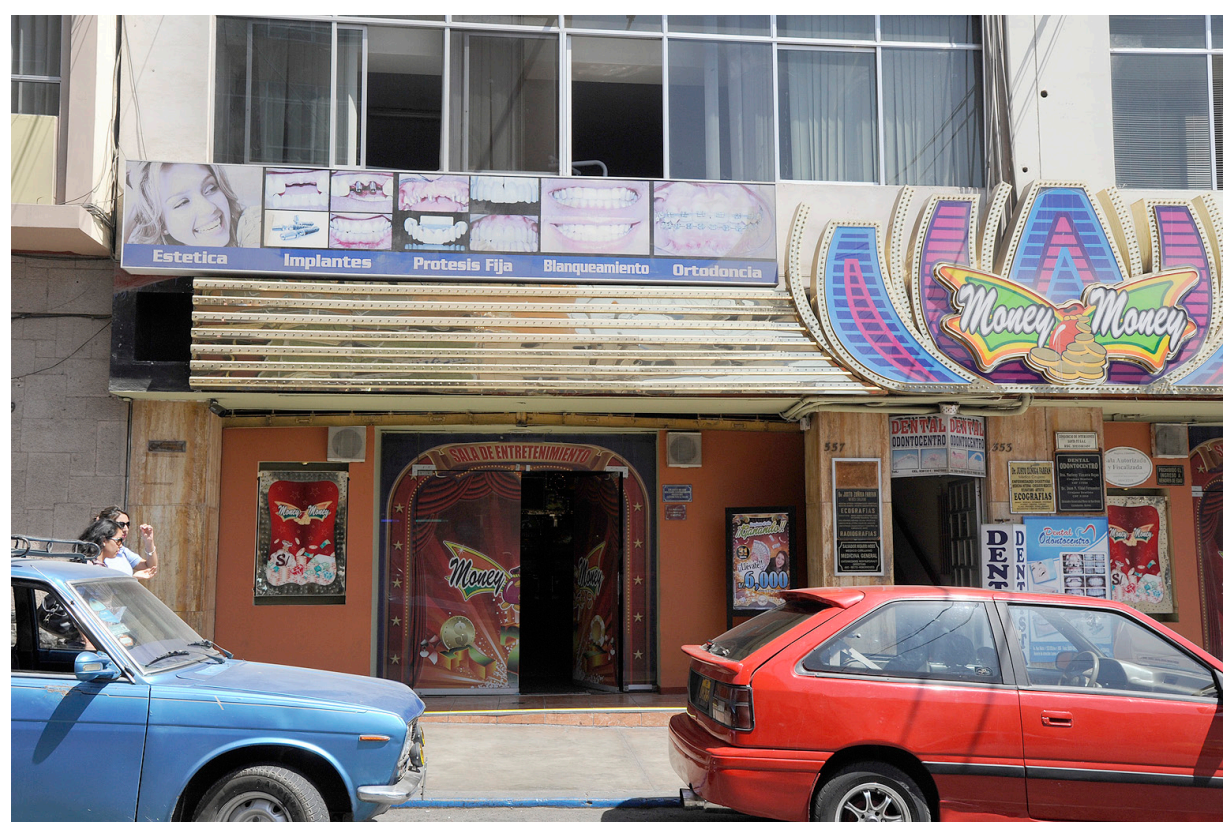

Figuras 1 y 2. "Centros dentales y casinos." Serie fotográfica Tacna. Paz Errázuriz. Archivo personal de la fotógrafa, 2014. 
FIGURA 3

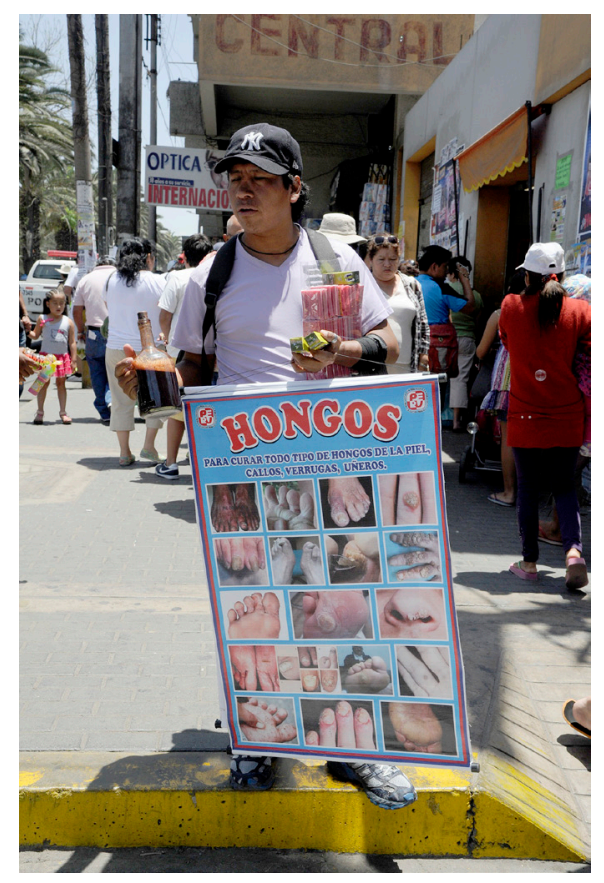

FIGURA 5

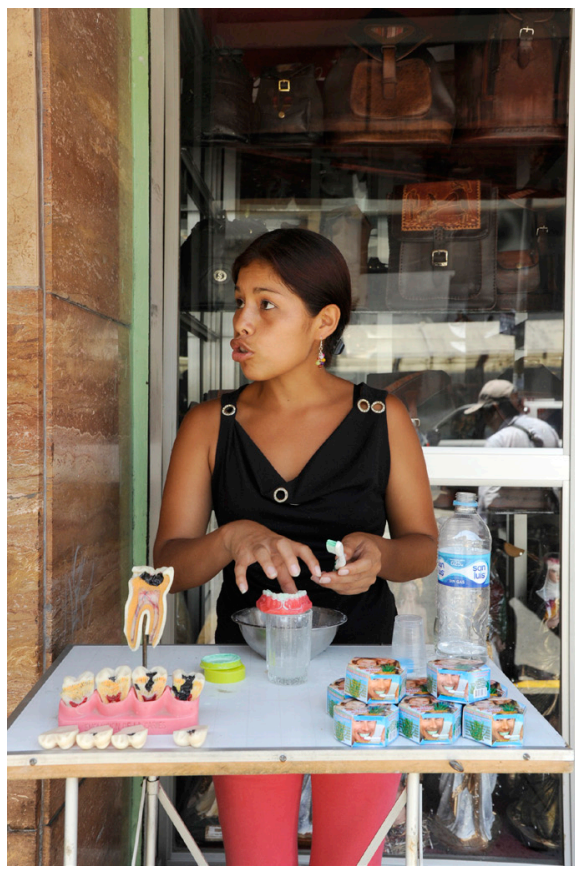

FIGURA 4

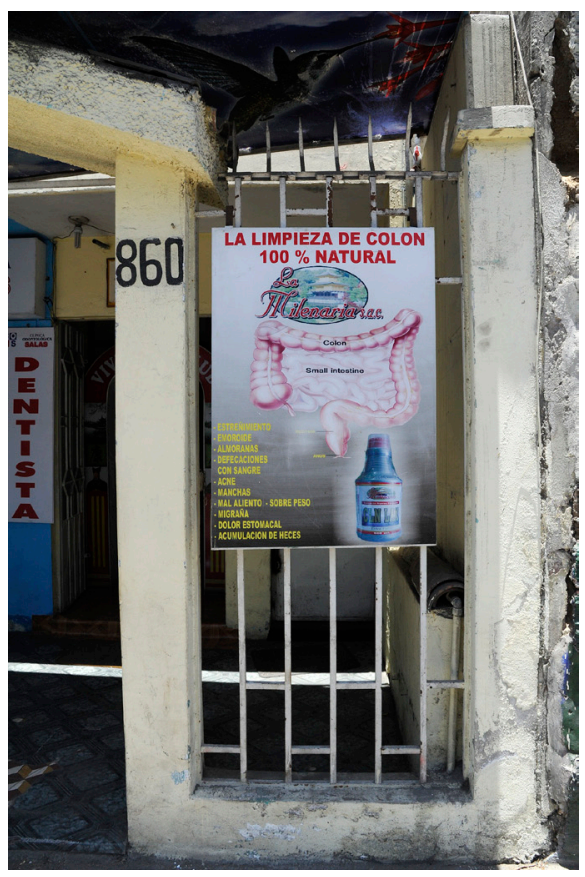

FIGURA 6

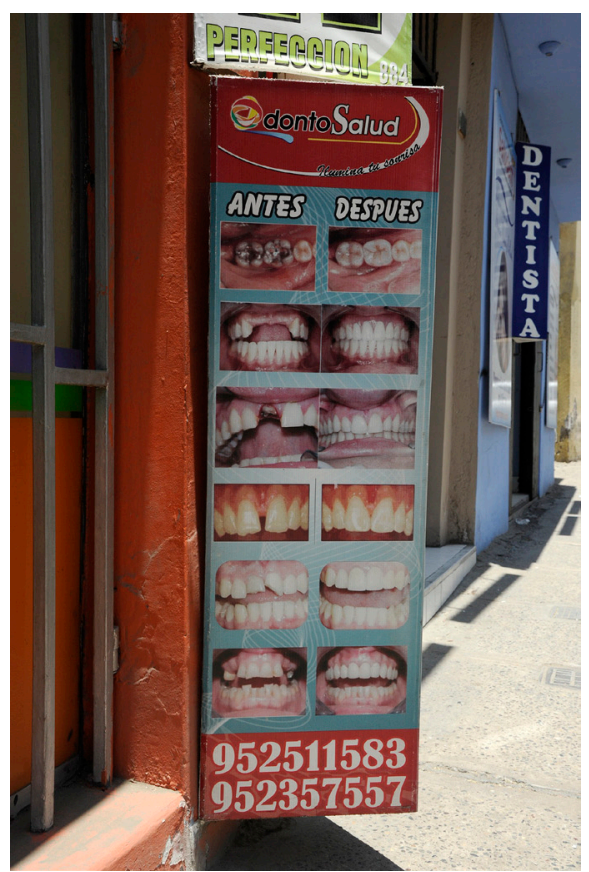




\section{FIGURA 7}

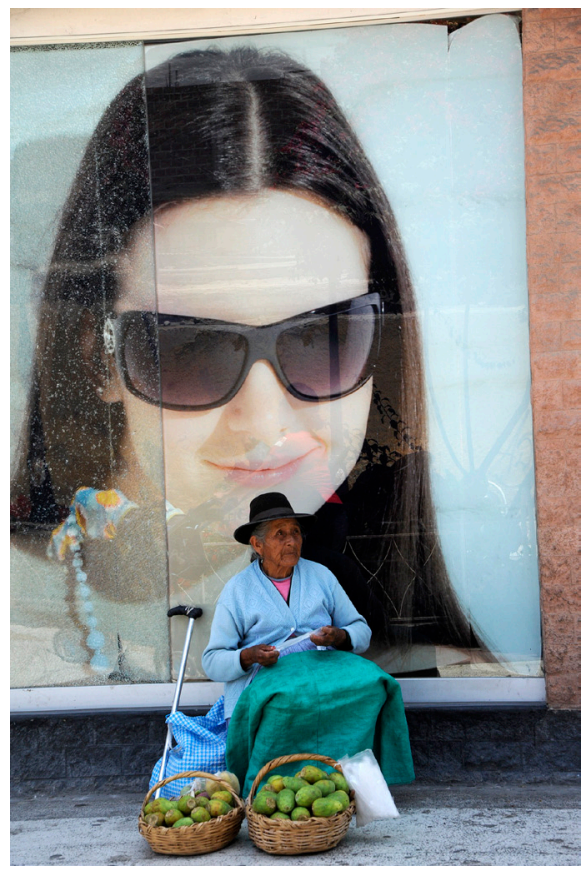

Figuras 3, 4, 5, 6, 7 y 8 . "Ofertas estéticas" Serie fotográfica Tacna. Paz Errázuriz. Archivo personal de la fotógrafa, 2014.

\section{FIGURA 8}

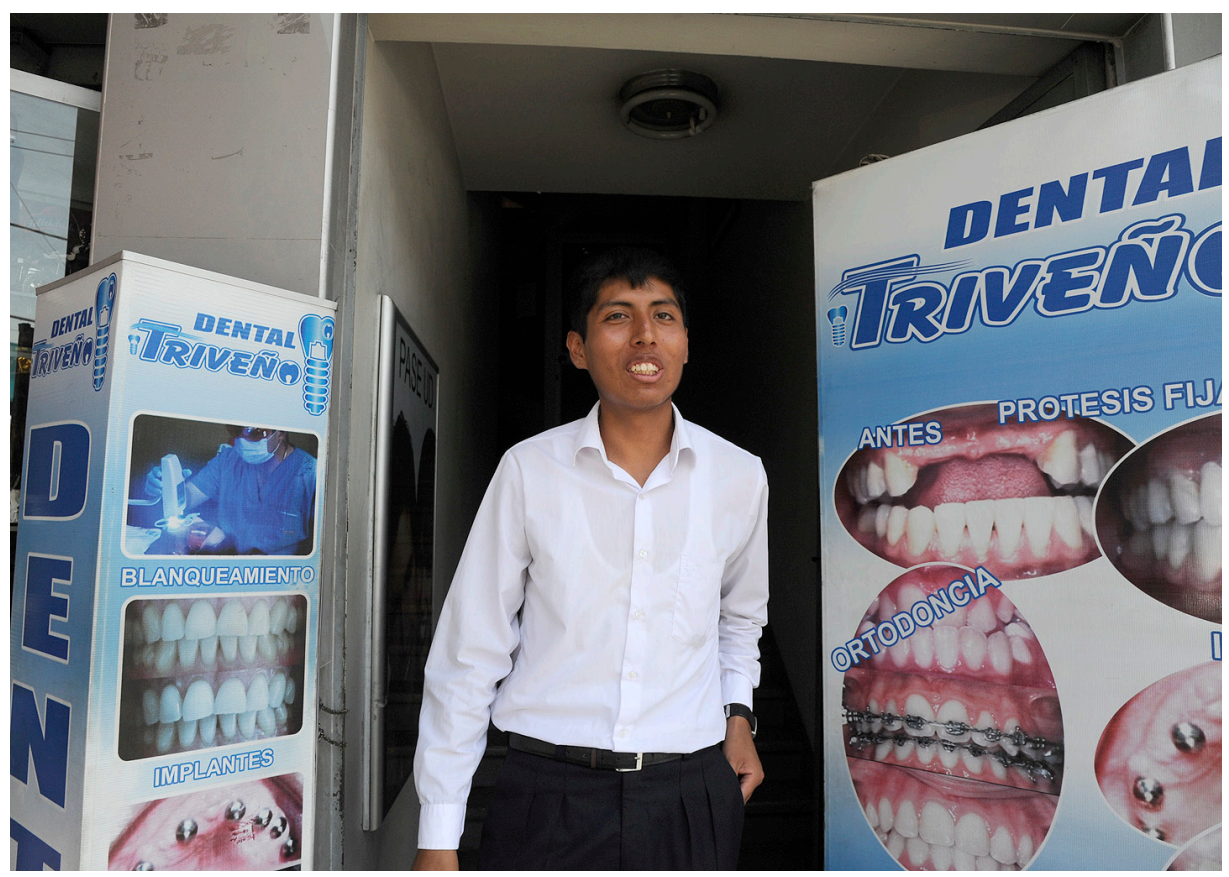




\section{FIGURA 9}

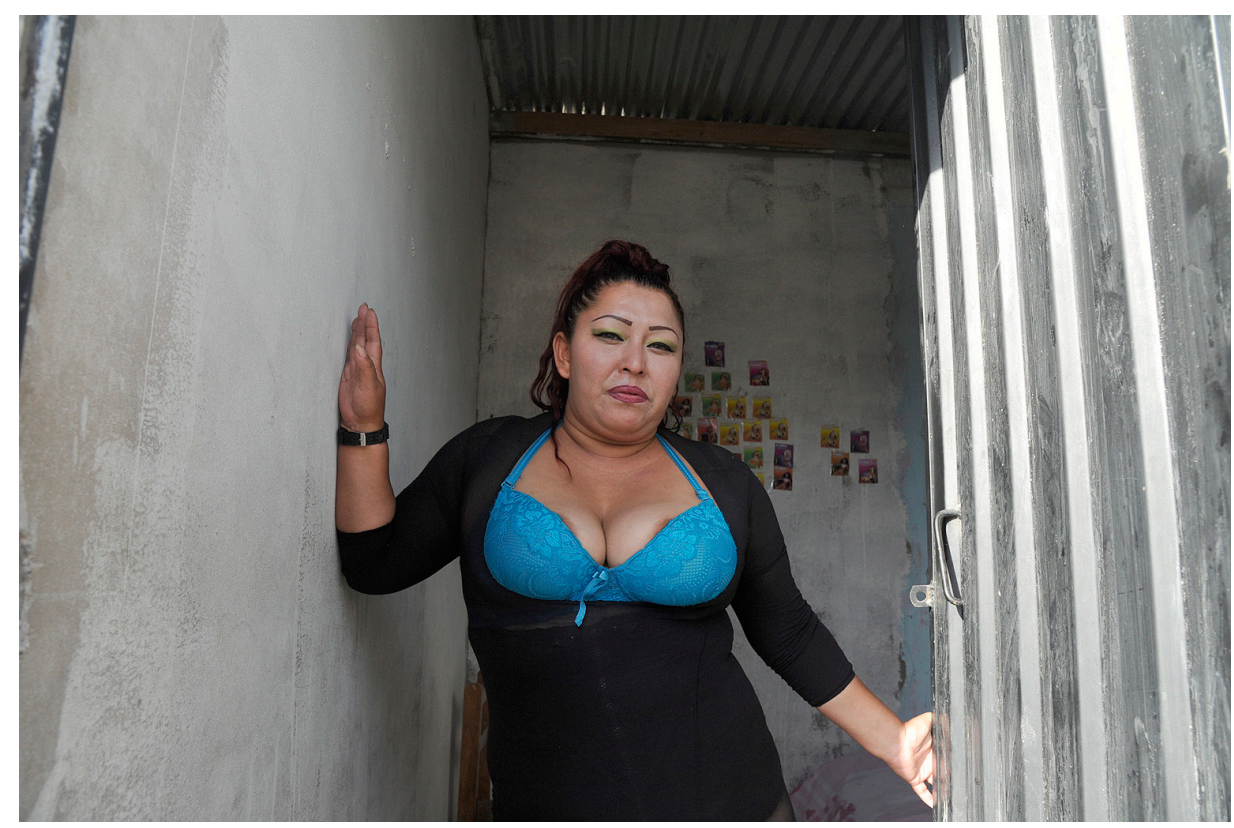

"Shirley en el Paraíso". Serie fotográfica Tacna. Paz Errázuriz. Archivo personal de la fotógrafa, 2014.

\section{FIGURA 10}

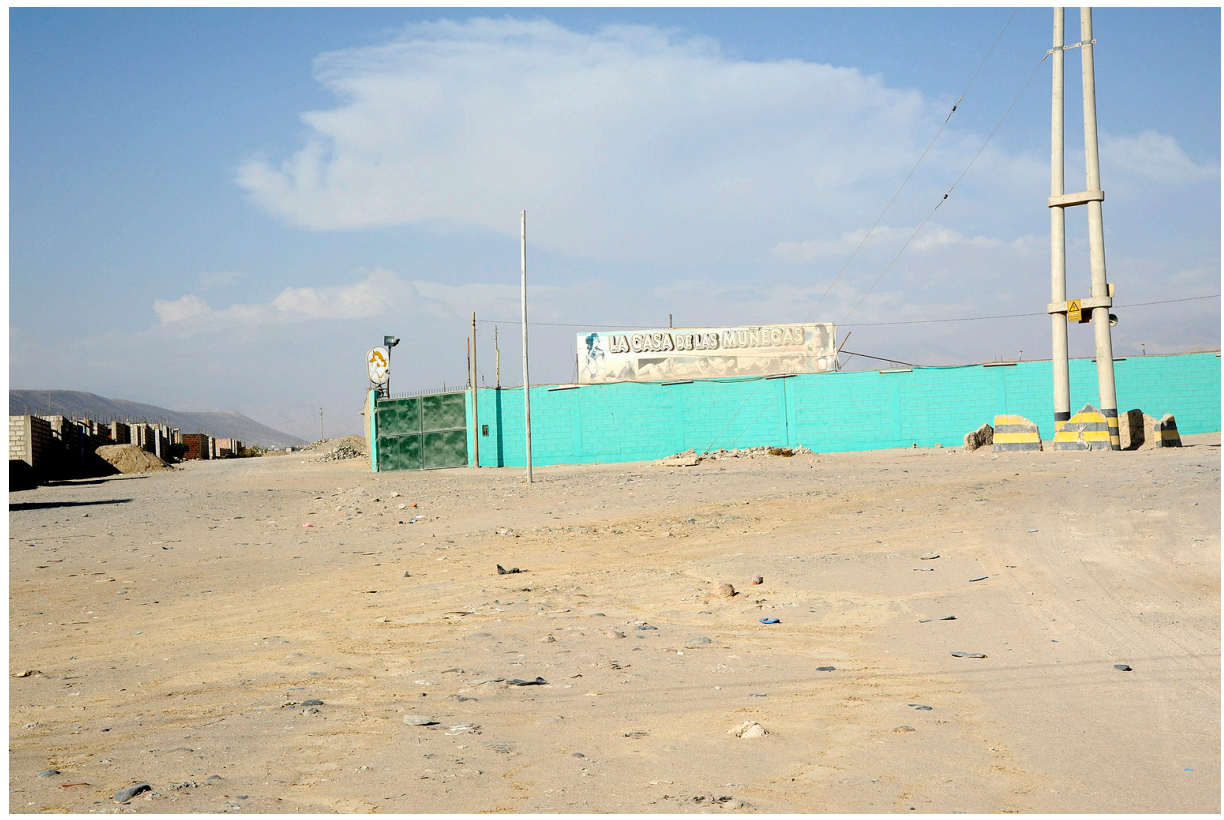

"Casa de muñecas". Prostíbulo abandonado en las afueras de la ciudad de Tacna. Serie fotográfica Tacna. Paz Errázuriz. Archivo personal de la fotógrafa, 2014. 
En el prostíbulo "Paraíso", ubicado en la periferia de Tacna, Shirley (fig. 9) posa en su habitación para la fotógrafa Paz Errázuriz. Shirley es ecuatoriana y ha viajado hasta los prostíbulos de Tacna como forma de subsistencia. El retrato de Paz Errázuriz pone en circulación los signos del cuerpo femenino explotado en la economía de los tráficos del borde. En la fotografía se desafía la mirada extranjera, en juegos pasajeros de poses y seducción que testifican la violencia de la pobreza, y a la vez otorgan la posibilidad de ser otra para esa mirada de la fotógrafa. En su modelaje fugaz, en las relaciones de Shirley posando, se rearman los cruces entre, por una parte, la visitante, espectadora, turista, documentalista o artista, y por otra, la de "objeto nativo", mujer inmigrante o prostituta. En el pacto de intercambios que se produce en la zona fronteriza del prostíbulo, la fotografía muestra una encrucijada de roles en disputa, donde Shirley puede ser seducida y seducir, exhibirse u ocultarse. La mirada fotográfica de Errázuriz aquí se desliza ambiguamente en la zona de contacto establecida entre ella y la mujer retratada. Shirley enseña una seriedad melancólica, enmarcada en el portal de su habitación de alquiler, donde hay un movimiento entre privado y público, pudor y fulgor obsceno, mostrando la fluctuación performativa de los roles.

En el lupanar fronterizo, en el laberinto donde la mujer se asoma para ofertar su cuerpo a la mirada pasajera del visitante, la cámara constata la violencia oculta sobre el cuerpo femenino como zona de venta, abuso y castigo. Si bien este retrato de Paz Errázuriz resembla el juego de deseo y poder entre turista cliente y mujer prostituta, permite mediante el acto de fotografiar, una nueva escena donde la inercia de la reiterada compraventa sexual se interrumpe por la mirada extraña e inusual de la fotógrafa. En este lidiar con la cámara, Shirley posa cómplice la melancolía de su coqueteo, la crudeza de la explotación sexual. La fotografía se debate aquí entre la mirada que reitera el placer escopofílico del que mira y la deferencia hacia la mujer que se retrata y que devuelve la mirada para interpelar al vouyerista. En esa reciprocidad surge efímera la posibilidad de que la retratada se reinvente para sobrevivir, y se dé el lujo de ser una estrella fugaz en los márgenes.

El efecto es testimonial y denunciante. Si en la serie "Tacna” observamos la relación entre recomposición orgánica del cuerpo enfermo (corrección de la muerte), en "Shirley" surge la tensión de cuerpos fronterizos expuestos y explotados al límite. Al publicar aquí las fotografías de este viaje en un mismo plano (este artículo), se desvirtúa el carácter artístico convencional de la fotografía única (retrato de autora), puesta en juego junto a una serie que podría ser la de un fotógrafo anónimo, lo cual pone en cuestión en parte la autoría, en el sentido de autoridad, de la fotógrafa como propietaria de la imagen del otro.

Concluyamos algunas ideas. En "Chalaco Amor" de Lemebel, la historia está determinada por la salida del territorio dictatorial chileno hacia Perú, como las aventuras de una loca pícara, cuyo protagonista se identifica con rasgos del otro peruano. La crónica de viaje pone en duda la alta literatura para desvirtuarse en letras plebeyas, siguiendo la deriva de una cartografía del deseo homosexual que burla por un tiempo 
las normas del discurso patriarcal y nacionalista. Así, Lemebel desplaza la letra a un espacio fronterizo que hace ambiguo al cuerpo y la identidad patriótica, y la travesía de la crónica es una estrategia de desterritorialización. Lemebel hace saltar el presente con el recuerdo del pasado (el viaje a Perú), y transforma la esquina del deseo de Santiago en un nuevo mapa que rearma los conflictos, donde las posiciones entre ser chileno y peruano, aunque mantienen sus diferencias, se desvirtúan e intercambian.

Algo semejante ocurre en el relato de Andrea Jeftanovic. Aquí también la memoria de la guerra, la violencia y los conflictos étnicos y nacionales resurge según nuevas yuxtaposiciones en el diálogo, posiciones que pervierten las perspectivas del sujeto y su mirada. "El Ojo de Watanabe" crea una carta de navegación (el cuento mismo) que desvía trayectorias y posiciones de poder, desmontando las relaciones fijas entre ficción y verdad, vida privada e historia nacional, mapa geopolítico y cartografías poéticas. Las escrituras de Lemebel y Jeftanovic son fronterizas porque descomponen los órdenes espaciales y temporales. En ellas se desarman los discursos patriotas, extrañando los símbolos comunes y dominantes de la identidad nacional y develando las invisibles condiciones históricas y materiales de producción de esos discursos.

En Camanchaca, una novela de ocultamientos e insinuaciones, como escritura desde la niebla, la violencia al otro peruano se manifiesta, sin alterar a los personajes, en el atropello final, como metáfora xenofóbica de una chilenidad miope y asfixiante. El protagonista de esta novela apenas comprende su pasado, mientras habita como joven taciturno, apático, encapsulado por el tedio adolescente en un Chile neoliberal. La salida a Tacna y el paso por la frontera es también un viaje de introspección. El otro aparece como un fantasma sin rostro, un nadie, que acecha sin embargo en la neblina del desierto. La invisibilidad de los otros en la escena final de Camanchaca se representa como ánimas en la niebla que no podemos ver, simbolizar, representar, pero que sin embargo permanecen y acosan al protagonista desde el otro lado, acaso el de los muertos vivientes.

En las fotografías de Paz Errázuriz realizadas en Tacna, he presentado una primera serie que registra la ironía y obscenidad de la ciudad fronteriza, ciudad transformada en sus fachadas de calles y vitrinas, ofertando servicios estéticos yuxtapuestos con la posible fortuna fácil de los casinos. Irónicamente, los letreros que prometen la limpieza del cuerpo y sus apariencias enseñan la frontera entre lo bello apolíneo de la blancura y lo macabro de las incontables imperfecciones y podredumbres físicas. Al descontextualizar la función original de la foto (el cartel callejero o "humano" que promociona la limpieza), el primer registro de Errázuriz captura el proceso mediante el cual la ciudad se inventa para la mirada chilena. Como resultado, las imágenes de la boca y sus deformaciones infinitas denotan negativos de la sonrisa publicitaria, que es pareja, blanca, sin identidad. El registro visual de Errázuriz, al descontextualizar y distanciar la fotografía publicitaria de sí misma y hacer fotos de fotos, muestra el conflicto de la serialidad de las mercancías dentales, imágenes dominadas por el canon caucásico que involucra la estética kitsch de clínica de belleza, con el horror 
de la boca deforme y sus signos de imperfección y suciedad, que son también el lado oculto en la ciudad-espejo. La inclusión aquí del retrato de Shirley, por una parte, y el prostíbulo en ruinas, por otra, pone de manifiesto y es la prueba testimonial del cuerpo oculto tras la fachada, en este caso, de la mujer explotada en la economía de intercambios desiguales que promueve el comercio transfronterizo.

\section{Referencias}

Baily, Jaime. “Jaime Baily y los chilenos.” El Mostrador. [Santiago, Chile] 24 Feb. 2011. Web. 3 Jun. 2016.

Balibar, Étienne. Politics and the Other Side. Nueva York: Verso, 2002. Impreso.

Borges, Jorge Luis. El etnógrafo. 1969. http://investigacionsocial.sociales.uba.ar/ files/2013/09/El-etnografo.pdf. Web. 1 Jun. 2014.

Chambers, Ian. "A line in the sand". Tijuana dreaming: life and art at the global border. Ed. Josh Kun y Fiamma Montezemolo. Durham: Duke University Press, 2012. IX-XIX. Impreso.

Deleuze, Gilles y Claire Parnet. Diálogos. Valencia: Pre-Textos, 1980. Impreso.

Errázuriz, Paz. “Tacna”. Serie fotográfica, colección personal de la fotógrafa. Santiago de Chile, 2014.

Fundación Imagen Chile. "Imagen de Chile en Perú 2009”. Encuesta. <http://www. imagendechile.cl/>. Web. 1 Jun 2014.

Larraín, Sergio. Identidad chilena. Santiago: Lom, 2001. Impreso.

Lemebel, Pedro. "Chalaco amor (sinopsis de novela)." Adiós mariquita linda. Santiago de Chile: Random House Mondadori, 2004. 109-133. Impreso.

Jeftanovic, Andrea. "El ojo de Watanabe." .cl Textos de frontera. Ed. Andrea Jeftanovic y Betariz García Huidobro. Santiago: Ediciones Universidad Alberto Hurtado, 2012. 359-370. Impreso.

“Racismo en Chile indigna a congresistas”. El Correo. [Lima, Perú] 18 Nov. 2014. Web. 1 Jun. 2016.

Richard, Nelly. "Éxodos, muerte y travestismo". Nomadías 8 (2008): 155-162. Web. 26 Feb. 2014.

Stefoni Espinoza, Carolina. La inmigración peruana en Chile. Una oportunidad de integración. Santiago: Universitaria, 2002.

Subercaseaux, Bernardo. "Caminos interferidos: de lo político a lo cultural”. Estudios Públicos 73 (1999): 150-154. Impreso.

Zúñiga, Diego. Camanchaca. Santiago: Mondadori, 2012. Impreso.

Recibido: 24 marzo 2014

Aceptado: 19 abril 2016 